of the building, but that even if they had, the necessity shown would have outweighed the adverse effect. ${ }^{3}$ [WA]

doi:10.1017/So956618X1000102X

\title{
Hashwani v Jivraj
}

Court of Appeal: More-Bick, Aikens and Buxton LJJ, June 2010 Arbitration - Equality (Religion and Belief) (Amendment) Regulations 2003

The court heard an appeal against the judgment of David Steel J sitting in the Commercial Court (noted at (2010) 12 Ecc LJ 121). The parties had been business associates who had agreed that if arbitration in the case of the winding up of their joint venture were to take place that the arbitrator appointed must be a member of the Ismaili Muslim community. One party had appointed an arbitrator from outside that community. The Commercial Court had held that the Equality (Religion and Belief) (Amendment) Regulations 2003 did not apply as an arbitrator was not an employee as covered by the regulations and thus that the appointment of an arbitrator from outside the community was void. The Court of Appeal upheld the appeal in part. The 2003 Regulations did apply to the appointment of arbitrators and being a member of this particular community was not a genuine occupational requirement under the regulations for carrying out the task. However, the striking out of the requirement for any arbitrator to be an Ismaili Muslim was held to invalidate the whole of the pertinent clause of the parties' agreement. Thus the ruling that the appointment of the arbitrator in question was void was upheld. [WA]

doi:10.1017/So956618X10001031

\section{Re St Andrew, Sedbergh \\ Bradford Consistory Court: Walford Ch, July 2010 \\ Cross - aesthetics - doctrinal objections}

The petitioners sought a faculty to hang an ebony and ivory cross above the pulpit. Seventeen of the twenty-two PCC members present had voted in favour of the proposal and four against. The DAC supported the petition. One of the PCC members who had voted against the proposal objected to the grant of a faculty on doctrinal and aesthetic grounds. No other objections had 
been raised. The chancellor did not consider it appropriate for him to seek to resolve sensitive and difficult doctrinal issues, nor to apply his own subjective aesthetic judgment. Having regard to the support of the DAC and the majority of the PCC, the chancellor held that the will of the majority should prevail and granted the faculty. [RA]

doi:10.1017/So956618X10001043

\section{Re Hagley Municipal Cemetery \\ Worcester Consistory Court: Mynors Ch, July 2010 Exhumation - Roman Catholicism}

The deceased and his widow were both Roman Catholics. The widow petitioned for the exhumation of the deceased's remains from the consecrated area of the local municipal cemetery for their re-interment in the local Roman Catholic cemetery. She argued that exceptional circumstances existed on the basis of mistake in that she had not previously known that a Roman Catholic cemetery existed in the area, that the plot in which her husband was buried was unsafe and vulnerable to a landslip and that the direction in which her husband had been buried was incorrect. The evidence did not support these arguments and the chancellor rejected them accordingly. Nevertheless, the chancellor considered the decision in $R e$ Putney Vale Cemetery ${ }^{4}$ and held that a mistake had been made sufficient to amount to exceptional circumstances in that the widow had no understanding of the nature and significance of consecration and therefore did not fully appreciate the permanence of burial in consecrated ground. A faculty was granted. [RA]

doi:10.1017/So956618X10001055

\section{Re Bromsgrove Old Cemetery}

Worcester Consistory Court: Mynors Ch, July 2010

Exhumation - scattering of ashes

The deceased's widow petitioned for a faculty for the exhumation of the deceased's cremated remains from the consecrated area of the local municipal cemetery in order that she could scatter them in accordance with his dying wishes. During the last 15 years of his life the deceased had been confined to a wheelchair and had expressed a desire for his remains to be scattered in order that he 'at last could be free'. The widow acknowledged that she had 'selfishly' 